\title{
Lifetime Achievement Award: F. Griffith Pearson
}

Joel D. Cooper, MD

From the Division of Thoracic Surgery, Hospital of the University of Pennsylvania, Philadelphia, $\mathrm{Pa}$.

Presented at the Eighty-fourth Annual Meeting of The American Association for Thoracic Surgery, Toronto, Ontario, Canada, April 25-28, 2004.

Received for publication May 4, 2005; revisions received Feb 1, 2006; accepted for publication March 15, 2006.

Address for reprints: Joel D. Cooper, MD, Division of Thoracic Surgery, Hospital of the University of Pennsylvania, 3400 Spruce St, 6 Silverstein, Philadelphia, PA 19104 (E-mail: joel.cooper@uphs.upenn.edu).

J Thorac Cardiovasc Surg 2006;132:453-4

$0022-5223 / \$ 32.00$

Copyright $(C) 2006$ by The American Association for Thoracic Surgery

doi:10.1016/j.jtcvs.2006.03.045
$\mathrm{T}$ The Nominating Committee of the American Association for Thoracic Surgery (AATS), consisting of the last 5 presidents of this association and chaired by Dr Larry Cohn, recently established a lifetime achievement award to be given from time to time to individuals who have made significant contributions to our specialty in the areas of patient care, teaching, research, or community service. On recommendation by the Nominating Committee and confirmation by the AATS Council, it was my great privilege to present the first AATS Lifetime Achievement Award to F. Griffith Pearson, MD.

Born in Toronto, Dr Pearson received his secondary education at the University of Toronto Schools, a coeducational high school affiliated with the University of Toronto. He went on to earn a medical degree and a Bachelor of Science degree at the University of Toronto. Dr Pearson played on the varsity hockey team both in high school and at the University of Toronto and was the silver medalist of his medical school class. After a rotating internship at the Toronto General Hospital, Dr Pearson spent a year in family practice at Port Colborne, Ontario. The following year, he returned to the University of Toronto as a research fellow with Dr Wilfred Bigelow, investigating hypothermia in hibernating groundhogs. Dr Pearson then had the opportunity to experience hypothermia firsthand: he returned to family practice for 3 years in the northern Ontario community of Wawa. In 1955, Dr Pearson returned to the University of Toronto, where he completed a residency in general surgery and became a Fellow of the Royal College of Surgeons in September 1958. In 1959-1960, Dr Pearson obtained a McLaughlin traveling fellowship, which he spent abroad. For the first 7 months, Dr Pearson was a senior house officer with Mr Ronald Belsey at the Frenchay regional thoracic unit outside of Bristol, England. He then visited Birmingham and London, England. The fellowship was completed with visits to Copenhagen, Aarhus, Malmo, Lund, Stockholm, and Oslo.

In 1960, Dr Pearson joined the general surgical staff at the Toronto General Hospital. In 1968, he accepted the invitation to head a new division of thoracic surgery at the Toronto General Hospital. In 1978, Dr Pearson became the surgeonin-chief of the Toronto General Hospital, a position he held for 11 years.

Dr Pearson has had a profound influence on the practice of thoracic surgery throughout the world. His contributions have been numerous and touch on all the major areas of general thoracic surgery. In 1963, after his McLaughlin fellowship to Great Britain and Scandinavia, Dr Pearson introduced mediastinoscopy into North American practice. He recognized early on its importance in the management of lung cancer. Its almost universal use today is testimony to his astute recognition of its value and his ability to teach and transmit the technique to others.

Dr Pearson's meticulous and scrupulously honest long-term assessment of patients undergoing antireflux repairs led him to recognize the contribution of an inflamed, shortened esophagus to less-than-ideal long-term results. His solution, the combination of an esophageal lengthening procedure, the collis gastroplasty, with the Belsey fundoplication, a combination often referred to as the Pearson procedure, remains standard practice today.

Dr Pearson made a number of important contributions to the field of experimental lung transplantation. I am personally indebted to him for focusing our group in Toronto on the goal of successful human lung transplantation.

Dr Pearson made many contributions to the field of airway surgery, but in my opinion his most important contributions were those related to the subglottic region, that difficult interface between the larynx and the trachea. 
Dr Pearson has been the senior editor of a major reference textbook, a magnum opus that is both practical and comprehensive.

Among Dr Pearson's many honors has been the presidency of this association. In December of 2004, the government of Canada recognized his contributions by presenting to him its highest honor, the Order of Canada.
In my opinion Dr Pearson's greatest contribution has been his effect on a whole generation of thoracic surgeons in North America, for whom he has been the prototype scholar, clinician, investigator, teacher, mentor, motivator, and friend. I owe so much of my career to his generosity, his enthusiastic support, and his deep and enduring friendship. It was a very special privilege for me to present Dr Pearson this award on behalf of the AATS.

\section{ON THE MOVE?}

Don't miss a single issue of the journal! To ensure prompt service when you change your address, please photocopy and complete the form below.

Please send your change of address notification at least six weeks before your move to ensure continued service. We regret we cannot guarantee replacement of issues missed due to late notification.

\section{JOURNAL TITLE:}

Fill in the title of the journal here.

\section{OLD ADDRESS:}

Affix the address label from a recent issue of the journal here.

\section{NEW ADDRESS:}

Clearly print your new address here.

Name

Address

City/State/ZIP
COPY AND MAIL THIS FORM TO:

Elsevier Inc.

Subscription Customer Service

6277 Sea Harbor Dr

Orlando, FL 32887
OR FAX TO:

407-363-9661

OR E-mail:

elspcs@elsevier.com
OR PHONE:

800-654-2452

Outside the U.S., call

407-345-4000 